\title{
FORECASTING THE DEVELOPMENT OF THE NUCLEAR INDUSTRIAL COMPLEX
}

\author{
Sergiy Drobot ${ }^{1}$
}

\begin{abstract}
The article is devoted to the development of an approach to forecasting the level of development of the nuclear industrial complex of Ukraine. The main purpose of this work is to forecast the level of development of the nuclear industry of Ukraine on the basis of the formed system of indicators that characterize both quantitative and qualitative changes in its operation. General scientific and special research methods, methods of analytical equalization, correlation and regression analysis, and scenario approach were used in the work, which in general allowed to fulfill the purpose of forecasting the level of development of the nuclear industrial complex of Ukraine. Statistical material on the indicators of attraction and use of production means, investment and innovation resources as the main sources of development of the nuclear industrial complex is collected and systematized. Growth rates that characterize quantitative and qualitative changes by sources of development are calculated; on this basis, an integrated assessment of the development of the nuclear industrial complex of Ukraine is given, its type is determined. An approach to forecasting the development of the nuclear industrial complex has been developed. Based on the developed approach, forecasting of development indicators was carried out. The forecast calculations have shown that in the forecast period it is possible to ensure further development with a focus on innovation, due to the increase of generalized indicators of development by its individual sources and the integrated indicator of development as a whole. The results of forecasting can create a basis for making sound management decisions in the field of managing the development of the nuclear industry.
\end{abstract}

Key words: nuclear energy, nuclear industrial complex, development, sources of development, production equipment, investment resources, innovation resources, forecasting, determinants, development scenarios.

JEL Classification: O11, O29, Q43

\section{The role of the nuclear industrial complex in the national economy of Ukraine}

Sustainable development of the national economy of Ukraine is inseparable from the development of the fuel and energy sector; nuclear energy is one of the highest priorities. In turn, the development of nuclear energy largely depends on how successfully the enterprises of the nuclear industrial complex, which create the appropriate raw material base, operate. The nuclear industrial complex, which is a leading part of Ukraine's nuclear energy complex, can be considered a complex sector of the national economy, including: uranium production, which creates a basis for meeting the needs of nuclear power plants in natural uranium in the medium and long term; zirconium production, which is the main structural material for the manufacture of nuclear fuel due to its unique physical properties of weak interaction with the neutron flux in the core of the reactor; production of ion exchange materials and providing uranium production of Ukraine with them in full; production of fuel assemblies and components as an integral part of creating its own nuclear fuel cycle; scientific, design and information support of R\&D. In 2019, the nuclear industrial complex of Ukraine, which includes SE NNEGC "Energoatom", SE VOSTGOK, Chornobyl NPP, Chornobyl Center, SSE Association Radon, and other enterprises and scientific institutions, formed total net income at the level of 164 billion UAH or $4.4 \%$ of the country's real $4 \%$ of GDP, which indicates its importance and the need for the projected government policy on the development of the nuclear industry. In 2019, the enterprises of the nuclear-industrial complex paid more than 64 billion UAH in taxes.

\footnotetext{
Corresponding author:

${ }^{1}$ Classic Private University, Ukraine

E-mail: drobot-sa@ukr.net

ORCID: https://orcid.org/0000-0002-0553-2247
} 
So, the nuclear industry has been attracting more and more attention. Today, the conditions of increasing instability and accelerated changes in the external environment force the enterprises of the complex to work in the mode of deterioration of the situation, which actualizes the problem of forecasting its future development in order to create a basis for strategically effective management decisions.

\section{Analytical assessment of quantitative and qualitative changes in the functioning of the nuclear industrial complex}

Problems of development of the fuel and energy complex of Ukraine and the nuclear industrial complex as its integral part are considered in the Energy Strategy of Ukraine until 2035 (Enerhetuchna stratehiia Ukrainy na period do $2035 \mathrm{roku})$. Theoretical and applied aspects of the study of the nuclear industrial complex and nuclear power industry were considered in the works by Lir V., Lytvynskyi L., Purtov O., Maksymchuk O., Mokhonko H., Tarasenko K., Shevtsov A., Doroshevych A. All the scientists emphasize the strategically important role of the nuclear industry not only for the development of the country's nuclear power industry but also for the development of the national economy as a whole. At the same time, the identification of promising areas of development of the nuclear industrial complex should be based not only on the assessment of sample indicators, which does not give a comprehensive picture of its level, but also take into account the influence of environmental factors - strategic determinants.

Operational data on the functioning of the enterprises of the nuclear industrial complex show that the costs of raw materials and materials of the nuclear industrial complex were quite significant. Labor costs throughout the study period experienced a fairly pronounced upward trend. At the same time, it should be noted that the increase in labor costs was due to the increase in the average wage, which occurred as a result of the recalculation of wages in order to bring them in line with the everincreasing minimum wage. Capital investments and investments in employee development changed rather unstable, with significant fluctuations.

On the basis of operational and analytical data, there were calculated coefficients that reflect the quantitative changes of indicators characterizing the activity of attracting production equipment, the activity of attracting investment resources, as well as the activity of attracting innovation resources. The values of these indicators are given in Table 1.

As Table 1 shows that 2009 (by 3.2\%), 2013 (by $8.4 \%$ ), 2016 and 2017 (by 1.0 and $21.0 \%$ respectively) were characterized by a decrease in raw materials and supplies. In other years of the study period, the cost of raw materials increased. At the same time, 2014 and 2015 were characterized by the largest growth, namely by 88.3 and $88.6 \%$ respectively.

As for labor costs, they experiences decrease only in 2009 (by 2.7\%). During the next period, there was an annual increase in labor costs, the maximum value of which was $23.3 \%$ in 2017.

Table 1

Indicators for assessing quantitative changes in the nuclear industrial complex of Ukraine

\begin{tabular}{|c|c|c|c|c|c|c|c|c|c|}
\hline Indicators & 2011 & 2012 & 2013 & 2014 & 2015 & 2016 & 2017 & 2018 & 2019 \\
\hline Coefficient of change in material expenditures & 0.968 & 1.210 & 1.083 & 1.180 & 0.916 & 1.883 & 1.886 & 0.990 & 0.790 \\
\hline Coefficient of change in labor costs & 0.973 & 1.062 & 1.074 & 1.097 & 1.049 & 1.027 & 1.170 & 1.195 & 1.233 \\
\hline $\begin{array}{c}\text { Indicator of quantitative changes in the field } \\
\text { of attracting production equipment }\end{array}$ & 0.970 & 1.134 & 1.078 & 1.138 & 0.980 & 1.391 & 1.485 & 1.088 & 0.987 \\
\hline \begin{tabular}{c} 
Coefficient of change in capital investments \\
\hline $\begin{array}{c}\text { Coefficient of change in investments } \\
\text { in employee development }\end{array}$
\end{tabular} & 0.808 & 0.977 & 1.242 & 0.317 & 0.704 & 1.454 & 0.746 & 1.279 & 1.019 \\
\hline $\begin{array}{c}\text { Indicator of quantitative changes in the field } \\
\text { of attracting investment resources }\end{array}$ & 0.807 & 0.927 & 1.048 & 0.669 & 0.937 & 1.197 & 0.971 & 1.241 & 1.140 \\
\hline Coefficient of change in R\&D funding & 0.950 & 0.827 & 0.567 & 0.800 & 0.893 & 1.080 & 0.629 & 0.317 & 0.934 \\
\hline $\begin{array}{c}\text { Coefficient of change in expenditures } \\
\text { in innovation activity }\end{array}$ & 0.979 & 1.096 & 1.336 & 1.053 & 0.967 & 0.995 & 1.042 & 1.014 & 1.006 \\
\hline $\begin{array}{c}\text { Indicator of quantitative changes in the field } \\
\text { of attracting innovation resources }\end{array}$ & 0.964 & 0.952 & 0.870 & 0.918 & 0.929 & 1.037 & 0.810 & 0.567 & 0.969 \\
\hline
\end{tabular}

Source: calculated on the base of (Zvitnist Derzhavnoho kontsernu "Yaderne palyvo") 
Capital investments were characterized by much less stability and the absence of a pronounced tendency to change. If in 2009 the value of capital investments decreased by $19.2 \%$, then in 2010 the value of this indicator decreased by $2.3 \%$. The following year was marked by an increase in the volume of capital investments by $24.2 \%$, while in 2012 and 2013 their value decreased by 68.3 and $29.6 \%$ respectively. In 2014, capital investments increased by $45.4 \%$.

However, the growth was not long-lasting and it was replaced by a significant reduction (by $25.4 \%$ ). The previous two years showed an increase in capital investment. However, if in 2016 their volumes increased by 27.9, then in 2017, an increase was only by $1.9 \%$, respectively.

In terms of investments in employee development, they were also characterized by significant fluctuations: the decline in 2011-2013 (by $19.3 \%, 12.0$ and $11.6 \%$, respectively) and in 2016 (by $1.4 \%$ ), then replaced by growth in 2014-2015 (by 41.3 and 24.8\%, respectively) and in the last three years of the study period, during which investments in personnel development grew by $26.5 \%, 20.5 \%$, and $27.6 \%$.

R\&D funding volumes increased slightly in 2016 (by $8.0 \%$ ). During all other years of the study period, R\&D funding decreased.

Regarding the expenditures in innovation activity, their dynamics differed slightly from the previous figure. Their value increased throughout the study period, except for the rime periods of 2011, 2015-2016, when there was a decrease in this indicator by $2.1 \%, 3.3$, and $0.5 \%$ respectively.
Based on the values of the coefficients, indicators of quantitative changes by sources of development were calculated. According to the results of the assessment, quantitative changes in the field of attracting means of production can be considered progressive in all years of the study period, except 2011 and 2019. Quantitative changes in the field of attracting investment resources were progressive in 2013 and 2016, 2018 and 2019. In all other years of the study period, quantitative changes in the field of attracting investment resources cannot be considered progressive. Regarding the quantitative changes in the field of attracting innovation resources, unfortunately, they were progressive only in 2016.

Based on the analyzed data by source (Zvitnist Derzhavnoho kontsernu "Yaderne palyvo"), the indicators of qualitative changes in the nuclear industrial complex of Ukraine were calculated (Table 2).

Based on the values of the coefficients, aggregate indicators of qualitative changes by sources of development were calculated. Calculations have shown that qualitative changes in the field of attracting production equipment can be considered progressive only in 2013, 2017 and 2019. Qualitative changes in the field of attracting investment resources were progressive for most years of the study period except 2016 and 2018. Regarding the qualitative changes in the field of attracting innovative resources, unfortunately, they were progressive throughout the study period, except for 2011 and 2016.

Table 2

Indicators for assessing qualitative changes in the nuclear industrial complex of Ukraine

\begin{tabular}{|c|c|c|c|c|c|c|c|c|c|}
\hline Indicators & 2011 & 2012 & 2013 & 2014 & 2015 & 2016 & 2017 & 2018 & 2019 \\
\hline Growth rate of sales per 1 UAH of material expenditures & 1.000 & 0.883 & 1.189 & 0.869 & 0.901 & 0.682 & 1.081 & 0.955 & 1.522 \\
\hline Growth rate of sales per $1 \mathrm{UAH}$ of labor costs & 0.994 & 1.006 & .199 & 0.935 & 0.998 & 0.986 & 1.742 & 0.791 & 0.975 \\
\hline $\begin{array}{c}\text { Indicator of qualitative changes in the field of attracting } \\
\text { production equipment }\end{array}$ & 0.997 & 0.942 & 1.194 & 0.901 & 0.948 & 0.820 & 1.372 & 0.870 & 1.219 \\
\hline Growth rate of sales per $1 \mathrm{UAH}$ of capital investment & 1.090 & 1.093 & .037 & 3.240 & 1.488 & 0.696 & 2.731 & 0.739 & 1.180 \\
\hline $\begin{array}{l}\text { Growth rate of sales per } 1 \mathrm{UAH} \text { of investments } \\
\text { in employee development }\end{array}$ & 1.092 & 1.214 & 1.457 & 0.726 & 0.839 & 1.026 & 1.611 & 0.785 & 0.943 \\
\hline $\begin{array}{c}\text { Indicator of qualitative changes in the field of attracting } \\
\text { investment resources }\end{array}$ & 1.091 & 1.152 & 1.229 & 1.534 & 1.117 & 0.845 & 2.098 & 0.762 & 1.055 \\
\hline Growth rate of sales per $1 \mathrm{UAH}$ of R\&D funding costs & 1.019 & 1.292 & 271 & 1.282 & 1.172 & 0.937 & 2.360 & 2.979 & 1.288 \\
\hline $\begin{array}{l}\text { Growth rate of sales per } 1 \text { UAH of expenditures } \\
\text { in innovation activity }\end{array}$ & 0.979 & 0.974 & 0.963 & 0.974 & 1.082 & 1.018 & 1.956 & 0.933 & 1.195 \\
\hline $\begin{array}{l}\text { Indicator of qualitative changes in the field } \\
\text { of attracting investment resources }\end{array}$ & 0.998 & 1.122 & 1.479 & 1.118 & 1.126 & 0.976 & 2.149 & 1.667 & 1.241 \\
\hline
\end{tabular}

Source: calculated on the basis of (Zvitnist Derzhavnoho kontsernu "Yaderne palyvo") 
Vol. 1, No. 2, 2020

Green, Blue \& Digital Economy Journal

Table 3

Results of the assessment of the development

of the nuclear industrial complex of Ukraine according to its sources

\begin{tabular}{|c|c|c|c|c|c|c|c|c|c|}
\hline Indicators & 2011 & 2012 & 2013 & 2014 & 2015 & 2016 & 2017 & 2018 & 2019 \\
\hline $\begin{array}{c}\text { Aggregate indicator of development in the } \\
\text { field of attracting production equipment }\end{array}$ & 0.986 & 1.022 & 1.146 & 1.000 & 0.962 & 1.059 & 1.420 & 0.960 & 1.122 \\
\hline $\begin{array}{c}\text { Aggregate indicator of development in the } \\
\text { field of attracting investment resources }\end{array}$ & 0.972 & 1.058 & 1.153 & 1.172 & 1.042 & 0.992 & 1.627 & 0.962 & 1.091 \\
\hline $\begin{array}{c}\text { Aggregate indicator of development in the } \\
\text { field of attracting innovation resources }\end{array}$ & 0.984 & 1.051 & 1.224 & 1.034 & 1.044 & 1.002 & 1.589 & 1.207 & 1.127 \\
\hline
\end{tabular}

Source: calculated on the basis of (Zvitnist Derzhavnoho kontsernu "Yaderne palyvo")

Table 4

Determining the type of development of the nuclear and industrial complex of Ukraine

\begin{tabular}{|c|c|c|c|c|c|c|c|c|c|}
\hline Indicators, thous UAH & 2011 & 2012 & 2013 & 2014 & 2015 & 2016 & 2017 & 2018 & 2019 \\
\hline$C a_{p}>C a_{i n v}$ & & & & & & & & & \\
\hline$C a_{i n v}>C a_{i n}$ & FACT & & & & & FACT & & & \\
\hline$C a_{p}>C a_{i n v}$ & & & & & & & & & \\
\hline$C a_{i n v}>C a_{i n}$ & & $I N V$ & $I N V$ & $I N V$ & & & $I N V$ & & \\
\hline$C a_{p}>C a_{i n v}$ & & & & & & & & & \\
\hline$C a_{i n v}>C a_{i n n}$ & & & & & $I N N$ & & & $I N N$ & $I N N$ \\
\hline
\end{tabular}

Source: formed by the author on the basis of his own calculations using (Zvitnist Derzhavnoho kontsernu "Yaderne palyvo")

Regarding the generalized indicators of development due to the involvement of different sources of development, the results of their calculation are given in Table 3 .

Regarding the aggregate indicator of development in the field of attracting innovation resources, it exceeded 1 during the entire study period, except for 2011. As can be seen from Table 3, quantitative and qualitative changes in the field of attracting production equipment were progressive in 2012-2013, 2016-2017, and in 2019. Other years of the period were not marked by progressive changes in this area.

The aggregate indicator of development in the field of attracting investment resources during the whole period except 2011,2016 and 2018 exceeded 1 , which testified to the progressive changes that have taken place in this sphere.

Based on statistical data on the nuclear and industrial complex for the period from 2011 to 2019, we will conduct an analytical assessment of the type of its development (Table 4).

As we can see from this table, during 2012-2014 and in 2017 the development of the nuclear and industrial complex was investment-oriented, in 2011 and 2016 it was factor-oriented. Innovationoriented type of development was observed in 2015 and 2018-2019.

\section{Selection and justification of the choice of models for forecasting indicators}

Based on statistical data on absolute indicators and the results of the assessment of the development of the nuclear and industrial complex of Ukraine according to its sources, the following trend lines were constructed:

1. Trend line for material expenditures:

$X_{1}=-40563,60+122370,85 \cdot N$

2. Labor cost trend line:

$X_{2}=209352,27+38896,52 \cdot N$

3. Capital investment trend line:

$X_{3}=378312,53-32327,01 \cdot N$

4. Personnel investment trend line:

$X_{4}=127,07+41,88 \cdot N$

5. R\&D funding trend line:

$X_{5}=40455,07-4027,41 \cdot N$

6. Trend line of expenditures in innovation activity:

$X_{6}=4256,93+288,45 \cdot N$

7. Trend line of sales volumes:

$X_{7}=300543+264583,38 \cdot N$

Based on these trend lines, adjusted values of development indicators were determined. The 
Table 5

Correlation coefficients for linear models for absolute indicators used in assessing the development of the nuclear industrial complex

\begin{tabular}{|c|c|c|c|}
\hline Indicator & $\begin{array}{c}\text { Value of the correlation } \\
\text { coefficient modulo }\end{array}$ & $\begin{array}{l}\text { Interpretation of the } \\
\text { correlation coefficient }\end{array}$ & Note \\
\hline $\begin{array}{l}\text { Condition of the sufficiency } \\
\text { of the correlation coefficient }\end{array}$ & $R_{I} \geq 0.7$ & $\begin{array}{c}\text { High or very high correlation } \\
\text { ratio }\end{array}$ & $\begin{array}{l}\text { If it is true, the correlation } \\
\text { ratio is considered sufficient }\end{array}$ \\
\hline Material expenditures & 0.863 & High correlation ratio & \multirow{7}{*}{$\begin{array}{l}\text { Correlation ratio is } \\
\text { sufficient. } \\
\text { Recommendations: } \\
\text { to check the models for } \\
\text { adequacy and credibility }\end{array}$} \\
\hline Labor costs & 0.910 & Very high correlation ratio & \\
\hline Capital investments & 0.815 & High correlation ratio & \\
\hline Investments for employee development & 0.856 & High correlation ratio & \\
\hline $\mathrm{R} \& \mathrm{D}$ funding & 0.944 & Very high correlation ratio & \\
\hline Expenditures in innovation activity & 0.864 & High correlation ratio & \\
\hline Sales volumes & 0.895 & Very high correlation ratio & \\
\hline
\end{tabular}

Source: developed by the author

Table 6

Verification of linear models for absolute indicators used in assessing the development of the nuclear industrial complex

\begin{tabular}{|c|c|c|c|}
\hline Indicator & $\begin{array}{l}\text { Model verification } \\
\text { by Student's t-test }\end{array}$ & $\begin{array}{l}\text { Model verification } \\
\text { by Fisher's F-test }\end{array}$ & Note \\
\hline $\begin{array}{l}\text { Condition of the sufficiency of the correlation } \\
\text { coefficient }\end{array}$ & $\begin{array}{l}\left|t_{p 0 I}\right|>t_{\kappa p} \\
\left|t_{p 1 I}\right|>t_{\kappa p}\end{array}$ & $F_{p}>F_{\kappa p}$ & $\begin{array}{l}\text { If it is true, the correlation ratio } \\
\text { is considered sufficient }\end{array}$ \\
\hline Material expenditures & $\begin{array}{l}2.58>2.31 \\
4.83>2.31\end{array}$ & $23.36>7.01$ & \multirow{7}{*}{$\begin{array}{l}\text { Correlation ratio is sufficient. } \\
\text { Recommendations: } \\
\text { to check the models for } \\
\text { adequacy and credibility }\end{array}$} \\
\hline Labor costs & $\begin{array}{l}5.38>2.31 \\
6.21>2.31\end{array}$ & $38.54>7.01$ & \\
\hline Capital investments & $\begin{array}{l}7.51>2.31 \\
3.98>2.31\end{array}$ & $15.83>7.01$ & \\
\hline Investments for employee development & $\begin{array}{l}3.29>2.31 \\
4.69>2.31\end{array}$ & $21.97>7.01$ & \\
\hline $\mathrm{R} \& \mathrm{D}$ funding & $\begin{array}{c}13.13>2.31 \\
8.11>2.31\end{array}$ & $65.78>7.01$ & \\
\hline Expenditures in innovation activity & $\begin{array}{c}11.56>2.31 \\
4.86>2.31\end{array}$ & $23.61>7.01$ & \\
\hline Sales volumes & $\begin{array}{l}10.4>2.31 \\
5.68>2.31\end{array}$ & $32.32>7.01$ & \\
\hline
\end{tabular}

Source: developed by the author

Table 7

Results of assessing predictability of conditionally controlled factors influencing innovation-oriented development

\begin{tabular}{|l|c|c|}
\hline \multicolumn{1}{|c|}{ Predictability impact assessment } & Predictability & Conclusion \\
\hline Material expenditures & 0.863 & $\begin{array}{c}\text { high predictability; } \\
\text { therefore, strategic } \\
\text { nature is defined }\end{array}$ \\
\cline { 1 - 2 } Labor costs & 0.910 & 0.815 \\
\cline { 1 - 2 } Capital investments & 0.856 & \\
\cline { 1 - 2 } Investments for employee development & 0.701 & 0.750 \\
\cline { 1 - 2 } Sales volume per 1 UAH of material expenditures & 0.903 & \\
\cline { 1 - 2 } Sales volume per 1 UAH of capital investments & 0.763 & \\
\hline Sales volume per 1 UAH of investments for employee development & & \\
\hline
\end{tabular}

Source: developed by the author 
predictability was checked using a correlation coefficient based on the trend model built for them.

Table 5 shows the correlation coefficients for linear models for absolute indicators of the development of the nuclear industrial complex and their interpretation.

As can be seen from Table 5, the coefficient ratio of the built models is sufficient, and therefore it can be recommended to check the models for adequacy and credibility.

The results of testing the models for adequacy and credibility are shown in Table 6 .

As can be seen from Table 6, the linear models are credible and adequate and can be used in further studies.

As we can see from the data in Table 7, all these factors can be considered strategic, i.e., determinants of development.

\section{Selection of determinants}

of innovation-oriented development

and forecasting the level of development of the nuclear industrial complex of Ukraine

Among these indicators, it is necessary to choose those that significantly affect the quantitative and qualitative changes in the field of innovation or reorientation coefficient on an innovative basis (assess the strength of the impact on a particular development indicator based on the pairwise correlation coefficient). If at least one of the parameters is strong, then it is a determinant of innovation-oriented development. Among those, there were selected the parameters that are determinants of innovation-oriented development based on the selection of those the impact of which on the indicator of quantitative or qualitative changes in the field of attracting innovation resources is strong in the calculated correlation coefficient (Figure 1).

To take into account external determinants, there is built a model of the dependence of the growth rate of the generalized development indicator on an innovative basis due to the influence of external factors on those that are determinants of external factors.

Taking into account the existing trends in external factors, which are determinants of innovation-oriented development, the values of its level were predicted according to the best- and worst-case scenarios (Table 4).

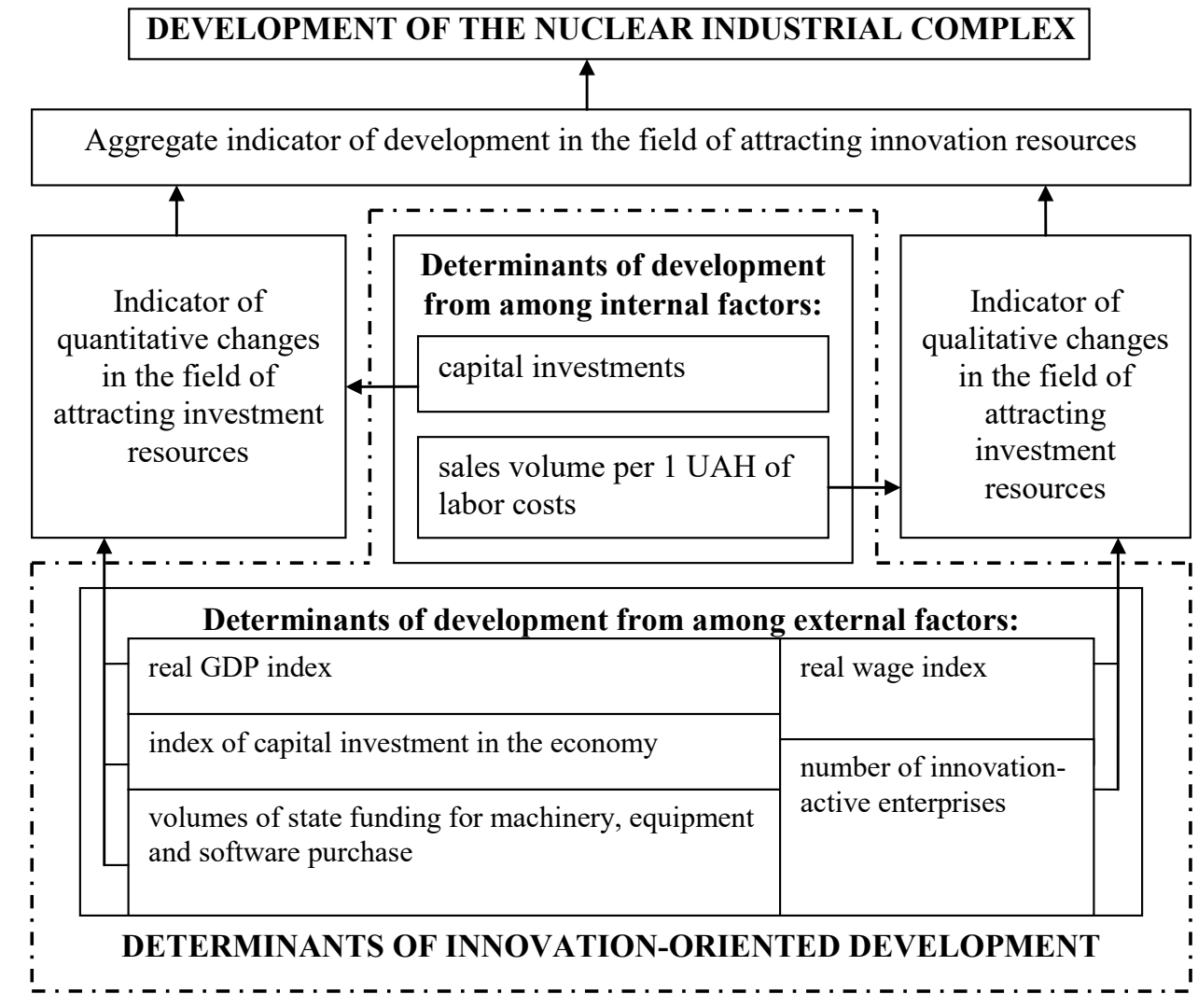

Figure 1. Selection of determinants of innovation-oriented development of the nuclear industrial complex of Ukraine 
Table 4

Results of construction of scenarios of innovation-oriented development of the nuclear industrial complex

\begin{tabular}{|c|c|c|c|}
\hline \multirow{2}{*}{ Indicator } & \multicolumn{3}{c|}{ Predicted value } \\
\cline { 2 - 4 } & Predicted year 1 & Predicted year 2 & Predicted year 3 \\
\hline \multicolumn{2}{|c|}{ Integral indicator of the development of the nuclear industrial complex } \\
\hline Basic scenario & 1.103 & 1.149 & 1.173 \\
\hline Best-case scenario & 1.110 & 1.156 & 1.181 \\
\hline Worst-case scenario & 1.099 & 1.145 & 1.171 \\
\hline Deviation from the basic scenario & & & $0.008 / 0.65 \%$ \\
\hline - from the best-case scenario & $0.007 / 0.63 \%$ & $0.007 / 0.65 \%$ & $-0.010 /-0.88 \%$ \\
\hline - from the worst-case scenario & $-0.011 /-1.0 \%$ & $-0.011 /-0.94 \%$ & \\
\hline
\end{tabular}

Source: calculated by the author

The data presented in Table 4 show that there is an urgent need to develop management decisions aimed at adapting to possible changes in the environment, which in turn will achieve the values of indicators in the best-case scenario.

\section{Findings}

Consequently, the forecasting of the development of the nuclear industrial complex made it possible to establish its type and level of development. The developed approach to forecasting the development of the nuclear industrial complex is based on a combination of methods of analytical alignment, correlation and regression analysis and scenario approach, which allows to determine the forecast values of development indicators and their change taking into account the influence of its determinants in the basic scenario. It also allows to build best-case and worst-case scenarios of innovation-oriented development of the nuclear industrial complex taking into account the projected impact of external development determinants. The projected change in indicators that are internal determinants was taken into account when forecasting by building a model of the dependence of the relevant development indicator (quantitative or qualitative changes in attracting innovation resources) from the determinant that determines the change in its value. Such an approach to evaluation creates a basis for the development of measures to increase the level of development of the nuclear industry and ensure its innovative orientation.

\section{Conclusions}

Studies have led to the conclusion that being an important component of the fuel and energy complex of Ukraine, the nuclear industrial complex contributes to the development of an energy independent state, which is difficult to overestimate. It is established that it strengthens the energy potential of the national economy, its economic security promotes the establishment of nuclear fuel production and its components to diversify its supplies and import substitution to meet the needs of nuclear power plants with raw materials of its own production. Given this, ensuring the development of the nuclear industrial complex of Ukraine is one of the priorities of management of the national economy. The importance of assessing changes in quantitative and qualitative indicators as a basis for forecasting the development of the nuclear industrial complex is substantiated. The necessity to take into account the influence of factors that change the tendencies inherent in the nuclear industrial complex has been proved when carrying out forecasting.

\section{References:}

Enerhetychna stratehiia Ukrainy na period do 2035 roku «Bezpeka, enerhoefektyvnist, konkurentospromozhnist»: Rozporiadzhennia Kabinetu Ministriv Ukrainy vid 18 serpnia $2017 \mathrm{r}$. no. 605-r / Kabinet Ministriv Ukrainy. Retrieved from: https://www.kmu.gov.ua/ua/npas/250250456

Vershynina, V. O. (2013). Stan ta zahalna otsinka rozvytku palyvno-enerhetychnoho kompleksu Ukrainy. Upravlinnia rozvytkom, no. 22, pp. 127-129. Retrieved from: http://nbuv.gov.ua/UJRN/ Uproz_2013_22_50 
Lir, V. E. (2017). Institutions and financial mechanisms of the development of nuclear power engineering of Ukraine. Ukrainian Journal of Applied Economics, no. 2, vol. 2, pp. 46-55.

Lytvynskyi, L. L., \& Purtov, O.A. (2006). Development of nuclear energy in Ukraine. Necessity, disadvantages and advantages. Retrieved from: http://www.kinr.kiev.ua/NPAE_Kyiv2006/proc/Litvinsky.pdf

Maksymchuk, O. S. (2013). Priority directions of state management of nuclear energy development and nuclear industry development in Ukraine. Public Administration: Theory and Practice, no. 1. Retrieved from: http://nbuv.gov.ua/UJRN/Patp_2013_1_16

Mokhonko, H. A., \& Tarasenko, K. V. (2018). Project Approach in Managing Innovative Development of Nuclear Power Industries. Economics and Society, no. 16, pp. 417-424.

Shevtsov, A., \& Doroshevych, A. (2006). Future of nuclear energy - in the latest technologies. Strategic priorities, no. 1, pp. 128-134.

Zvitnist Derzhavnoho kontsernu «Yaderne palyvo»: veb-sait. Retrieved from: http://www.nfuel.gov.ua/ aboutus/zvitnist/

Kyslova, L. A. (2017). Analysis of the functioning environment of the enterprises of the metallurgical industry of Ukraine. Bulletin of the Priazov State Technical University. Economic Sciences, no. 33, pp. 138-144. 